UDK 78.01:78 Bach

Jurij Snoj

Znanstvenoraziskovalni center SAZU, Ljubljana

Scientific Research Centre of the Slovenian Academy of Sciences and Arts

\title{
Johann Sebastian Bach: Ubesedljiva določnost glasboslovne sodbe in neubesedljiva veličina glasbe
}

\section{Povzetek}

Kot je razvidno iz Scheibejevega pisanja, so bile osebnostne lastnosti Bachove glasbe prepoznane že v njegovem času, kljub temu pa se je Bachova glasba začela pojmovati kot delo izrednega skladatelja šele stoletje po njegovi smrti. Ob tem se je v zgodovinskem procesu, ki je privedel do splošnega priznanja Bachove umetnosti, ta začela razumevati in obravnavati s koncepti, ki so bili tuji njenemu zgodovinskemu okolju. Kot posledica tega je prišlo do razkoraka med resničnim, zgodovinskim Bachom in njegovo kanonizirano podobo. V strokovni literaturi o Bachu je mnogo različnih opažanj in namigov v zvezi z veličino njegove glasbe. Natančnejša, deduktivno osnovana analiza takih mest kaže, da sicer lahko napeljujejo na misli o izrednosti Bachove glasbe, katere estetskega jedra pa vendarle ne morejo natančno izraziti. Na Bachovem življenju ni nič posebnega in njegova glasba, ki je nastajala predvsem za dejanske priložnosti, ne more biti razumljena kot osebna izpoved človeka $z$ izredno življenjsko usodo. Glasbenozgodovinopisni pristop k njegovemu delu z izjemo subjektivne kritiške presoje nima metodoloških sredstev, $s$ katerimi bi ga vrednostno primerjal bodisi $z$ deli njegovih predhodnikov ali sodobnikov. Domnevna religioznost Bachove glasbe zbledi, če jo primerjamo s standardi običajnega cerkvenoglasbenega delovanja njegove dobe. Religioznost kot kvaliteta njegove glasbe postane vpadljiva pravzaprav šele tedaj, ko se Bachova glasba gleda s stališča sodobnih sekulariziranih družb. Skrivna sporočila Bachovih glasbenih simbolov ne vplivajo na estetsko jedro njegove glasbe; čeprav kažejo na skladateljev odnos do samega sebe, poslušalcu ne povejo ničesar. Kar zadeva glasbenoanalitični pogled, je bila Schenkerjeva analitična metoda tista, ki je obljubljala prodrtje v globine mojstrove umetnosti; a opirajoč se na Scrutonovo kritiko je Schenkerjevo analizo mogoče razumeti zlasti kot analizo umetniške izkušnje Bachove glasbe, ne pa kot objektivno odkritje njene vsebine. Izhajajoč iz tega je Bachovo glasbo mogoče dojemati, razumevati in vrednotiti le znotraj glasbenega izkustva samega.

Vse od ponovne oživitve v prvi pol. 19. stol. dalje velja glasba J. S. Bacha za nekaj najpomembnejšega in največjega, kar je bilo glasbenega kdaj koli ustvarjeno. ${ }^{1} \mathrm{O}$ tem

Geiringer, K., Johann Sebastian Bach, München 1971, str. 350-351. 
priča predvsem glasbeno življenje samo, ki si ga brez prisotnosti Bachove glasbe ni mogoče zamišljati; o tem pričajo številne izjave prominentnih skladateljev, ki so v Bachovi glasbi - čeprav nastali neredko iz povsem drugačnih izhodišč kot njihova lastna - videli kompozicijski svet, vzbujajoč občudovanje in priznavanje; ne nazadnje priča o pomenu in prisotnosti zavesti o Bachovi glasbi tudi obseg raznovrstnega pisanja o njej: monografskega, glasbenoteoretskega, obravnavajočega izrecno kompozicijska vprašanja, glasbenozgodovinopisnega, kulturnozgodovinskega, teološkega in priložnostnega.

Ponovna oživitev Bachove glasbe v 19. stol. ni bila le odkritje nečesa, kar bi bilo glasbenemu svetu predhodnih obdobij povsem neznano, saj so imeli tudi že nekateri Bachovi sodobniki in neposredni nasledniki o njem kot skladatelju zelo visoko mnenje. Odkritje Bachove umetnosti in vzpostavitev kulta Bachove glasbe je bila gotovo povezana $z$ novim pojmovanjem umetnosti in umetnika: s pojmovanjem, ki je temeljilo na prepričanju o absolutni veljavi genialnega posameznika, ki kot umetnik nastopa nasproti družbi in se pojavlja na obzorju narodnostne, kulturne, umetniške ali glasbene javnosti. Prav zaradi tega ponovna oživitev Bachove glasbe ne zadeva le nje same, pač pa je neodtujljiv in celo bistven del glasbene zgodovine 19. stol.

V strokovni literaturi so vrednostne sodbe o posamičnih Bachovih delih in o njegovem opusu kot celoti številne in raznovrstne. Ob njih se lahko vprašamo: V čem vidijo poznavalci in razpravljalci veličino mojstrovega dela, izražajoč jo bodisi z izrecnimi besedami ali pa molče predpostavljajoč jo? Ali je Bachova glasba velika zato, ker je sinteza nemškega, italijanskega in francoskega in v tem smislu učinkovit spoj in združitev vsega tistega, kar je obstajalo v glasbi prve pol. 18. stol..?2 Ali pa je njena veličina v tem, da predstavlja kulminacijo dolgega predhodnega obdobja, katerega korenine segajo vsaj v začetek 17. stol., torej kulminacijo obdobja, ki ga tradicionalna umetnostnozgodovinska sistematika pojmuje kot barok?33 Ali je velika zato, ker je čist in iskren odraz nemškega protestantizma 17. in 18. stol., se pravi čist odraz religiozne drže v kulturni zgodovini Evrope nespregledljivega nemškega severa, ali pa morda zato, ker je izpoved globoko religioznega človeka, ki mu je prav njegova religioznost omogočala nenavadna, drugim nedostopna glasbena doživetja in videnja? Ali je veličina Bachove glasbe v tem, da izkazuje dosleden kompozicijski red, neizprosno glasbeno logiko, katere razumevanje je sicer dostopno zgolj glasbenemu intelektu, ki pa zaradi tega ni manj prepričljiva; $z$ drugimi besedami: ali je Bachova glasba velika zaradi nespornega, neverjetnega kompozicijskega mojstrstva? Ali pa je njena veličina v tem, da na idealen način združuje dvojost, ki jo je tradicionalna estetika pojmovala kot dvojost oblike in vsebine: da idealno združuje obliko in vsebino v tem smislu, da v Bachovi glasbi oblika - način izpeljave kompozicije iz danega motivičnega ali tematskega gradiva - nikoli ne moti glasbene pripovedi, tako da jo poslušalec vedno razume kot logično in samoumevno, kot si tudi glasbena pripoved sama vedno izbira najprikladnejšo glasbenooblikovno izpeljavo?

\footnotetext{
Tako gledanje nakazuje naslov poglavja o Bachu v klasičnem muzikološkem tekstu o glasbi v obdobju baroka: Bukofzer, M., Music in the Baroque Era, London 1948, str. 260 ("Fusion of National Styles: Bach").

Prim. podnaslov originalne angleške izdaje Geiringerjeve monografije: Geiringer, K., Johann Sebastian Bach. The Culmination of an Era, New York 1966.
} 
MUZIKOLOŠKI ZBORNIK • MUSICOLOGICAL ANNUAL XXXVI

Vse pravkar povzeto in še kaj se bolj ali manj izrecno navaja kot utemeljitev Bachove veličine; in vse to so - poleg drugega - toposi razmišljanja in razpravljanja o Bachovi umetnosti.

Vsaka od utemeljitev Bachove izjemnosti in veličine je možna kot plod lastnovrstnih, v sebi utemeljenih gledanj, razmišljanj in iskanj; zato je ta zapis bolj kot iskanje odgovorov na vprašanje, v čem je svojskost Bachove umetnosti, razmišljanje, esejistični sprehod po temah razpravljanja o Bachu in njegovi glasbi, ki jih v obrisih nakazujejo tudi argumentiranja o tem, v čem je veličina njegove umetnosti. Literatura o Bachu je tako nepregledno obsežna in raznovrstna, da bi izčrpnejši sistematični pogled nanjo, razumljivo, bil možen samo v zelo obsežni študiji, znatno presegajoči okvire tega zapisa. Ta ima namen pomuditi se le pri nekaterih vprašanjih, tipih razmišljanj in razpravljanj o Bachu in njegovi glasbi ali pa pri posamičnih sodbah o njej, jih predstaviti, komentirati, mestoma pa jih nadaljevati z lastnimi izpeljavami.

\section{Vprašanja Bachovega življenjepisa}

Arhivsko gradivo iz Bachovega časa in okolja je danes poznano do tolikšne mere, da v zvezi z Bachovim življenjem ni pričakovati odkritja novih, še nepoznanih dokumentov. To pomeni, da se partikularnemu vedenju o Bachovem življenju najbrž ne bo moglo dodati nič novega. Ali je s tem ta del ukvarjanja z Bachom zaključen in njegovo življenje poznano do meja možnega? Zdi se, da je tako; vendar pa to ne pomeni, da so arhivalije, ki so se v zvezi z Bachovim življenjem ohranile, tudi nedvoumno razumljive; zlasti pa ne pomeni, da njegova življenjska pot ne bi mogla biti videna na drugačen in nov način: Bachovega življenja oz. virov neposredno v zvezi z njim ni mogoče obravnavati neodvisno od njegovega okolja; pogled na tisto, kar neposredno govori o Bachu, je tako vedno odvisen od takega ali drugačnega videnja nemškega protestantskega severa, bodisi v gospodarskem, kulturnem, religioznem ali glasbenem smislu. Ker pa se pogled na nemško protestantstvo spreminja, so v določenem smislu spremenljive tudi podobe, ki si jih je mogoče ustvariti o življenjskih poteh posameznih ljudi.

Kot omenjeno, dopuščajo nekateri dokumenti v zvezi z Bachovim življenjem različne razlage in sklepe tudi glede tiste plasti Bachove biografije, ki jo je treba razumeti na ravni gole dejstvenosti. Na to je treba opozoriti zato, ker so nejasnosti v zvezi s tem, kaj ohranjeni dokumenti dejansko govorijo, v biografijah in monografijah pogosto zamolčane; bele lise Bachovega življenjepisa so tako marsikje zapolnjene z razpravljalčevo lastno razlago, ne da bi bil bralec na to opozorjen. Če smo natančni, moramo ugotoviti, da se npr. o Bachovem bivanju v Lübecku leta 1705 ne ve veliko. ${ }^{4}$ Poleg kasnejših pričevanj, med katerimi je zlasti po Bachovi smrti sestavljeni nekrolog, ${ }^{5}$ je pravzaprav glavni vir, ki govori o tem, skop. Ko se je Bach vrnil iz Lübecka na svoje delovno mesto v Arnstadt, je bil poklican pred svoje predstojnike, pred cerkveni konzistorij, in sicer zato, ker se je predolgo mudil v Lübecku.

Dokumenti v zvezi z Bachovim življenjem so objavljeni v Bach-Dokumente, I-III, izd. W. Neumann in H.-J. Schulze, Kassel itd., Leipzig 1963, 1969, 1972. Tu so povzeti predvsem po delu Johann Sebastian Bach. Leben und Schaffen, izd. W. Reich, Zürich 1957.

V slovenskem prevodu: „Bachov nekrolog،, prev. M. Dušinc, Cerkveni glasbenik, 93, št. 1-3, str. 3. 
Bachovi odgovori, zabeleženi v protokolu zaslišanja, so kratki: bil je v Lübecku, da bi se izpopolnil v svojem poklicu; njegova odsotnost ni pozvročila škode, sajje imel v tem času namestnika. ${ }^{6}$ Navedbe o tem, da je šel v Lübeck peš, da se je tam udeleževal "večerne glasbe "(Abendmusiken), ki jo je v adventu leta 1705 Buxtehude resnično prirejal, ${ }^{7}$ so kasnejše domneve, ki izhajajo zlasti iz Bachovega nekrologa, čeprav je treba dodati, da je Bach poznal Buxtehudejeva dela, od katerih so se nekatera ohranila le prek Bachovih prepisov. ${ }^{8} \mathrm{Na}$ istem zaslišanju, ki je potekalo na gradu Neideck, se je poleg drugega Bachu očitalo tudi to, da njegova orgelska spremljava kongregacijskega petja ni primerna in da povzroča zmedo. ${ }^{9}$ Kako je mogoče razumeti ta očitek? Opazka Bachovih predstojnikov pove tako malo, da jo je mogoče razlagati na različne načine; lahko bi se nanašala tudi zgolj na priložnostno odstopanje od ustaljenega, običajnega, ki bi si ga mladi organist dovolil brez posebnega razloga, morda iz mladostniške lahkomiselnosti, še zlasti zato, ker ni znano, da bi bil Bach kot praktični spremljevalec kongregacijskega petja protestantskih koralov začetnik česa novega. Vendar pa nekatere monografije o Bachu ne upoštevajo nejasnosti obtožbe. Tako je Spitta videl v obtožbi znak Bachove genialnosti: mladi organist naj bi se prepustil glasbi ne oziraje se na praktični značaj in namen svoje spremljave. ${ }^{10}$

Na podoben način iz ohranjenih dokumentov ni razvidno, zakaj je Bach v Weimarju leta 1717 prenehal komponirati sakralne kantate: kot je znano, se ni ohranila iz tega leta nobena Bachova kantata in malo verjetno je, da bi bile vse izgubljene. Ker je 1. decembra 1716 umrl vodja weimarske dvorne kapele J. S. Drese, je verjetno, čeprav z viri nedokazano, da je Bach upal, da bo njegov naslednik. A zelo verjetno je enako upanje gojil tudi sin umrlega, ki je bil po rangu v kapeli namestnik vodje. Vendar pa weimarski knez s svojim soregentom - in morda prav zaradi stalnih sporov z njim - v zvezi s tem ni sprejel nobene odločitve in v letu 1717 weimarski dvor ni imel vodje kapele, saj je bil Dresejev sin imenovan za vodjo šele po Bachovem odhodu v Köthen. ${ }^{11}$ Zdi se, kot da bi Bach iz protesta, ker ni bil imenovan za kapelnikovega naslednika, prenehal komponirati religiozna dela. Vendar pa ta sicer pogosta razlaga ${ }^{12}$ ni povsem gotova. Od leta 1714 dalje, ko je Bach v Weimarju napredoval v koncertnega mojstra (z drugačnim delokrogom kot ga vključuje današnji pomen izraza), je imel pogodbo, po kateri naj bi vsake štiri tedne skomponiral novo kantato. Bachova zadnja weimarska kantata je bila izvedena na četrto adventno nedeljo $1716 .{ }^{13}$ Čeprav za sledečo domnevo ni dokazil in čeprav se leta 1717 Bachu ni zmanjšala plača, je vendarle možno, da mu je bilo delo, za katero je bil zadolžen s pogodbo iz leta 1714 , z letom 1717 odvzeto. ${ }^{14}$ Vprašanje, zakaj je Bach s tem letom prenehal pisati kantate, se ob dejstvu, da jih preprosto ni, sicer zdi manj pomembno, a takšna ali drugačna razlaga njihovega umanjkljaja je lahko tehten argument ob

Besedilo protokola zaslišanja $\mathrm{z}$ dne 21. 2. 1706: Reich, W., nav. delo, str. 25.

Snyder, K. J., "Abendmusik", Die Musik in Geschichte und Gegenwart. Sachteil, 1, Kassel itd. 1994, stolpca 13-14; Breig, W., "Bach, Johann Sebastian", Die Musik in Geschichte und Gegenwart. Personenteil, 1, Kassel itd. 1999, stolpec 1400.

Breig, W., nav. delo, stolpec 1400 .

9 Reich, W., nav. delo, str. 25-26.

Spitta, Ph., J. S. Bach, I, Leipzig 1930, str. 309-310. Pomenljivo je, da Schweitzer, četudi je bil sam organist, tega očitka Bachu ni komentiral: Schweitzer, A., Johann Sebastian Bach, Leipzig 1977, str. 95.

11 Breig, W., nav. delo, stolpec 1403.

12 Eggebrecht, H. H., Bach - wer ist das?, München 1992, str. 75-76.

13 BWV 147a.

14 Breig, W., nav. delo, stolpec 1403. 
pretehtavanju drugih vprašanj: Tako vidi Eggebrecht v Bachovi domnevno protestni prekinitvi komponiranja sakralnih kantat kazalec, da je Bach komponiral religiozna dela predvsem po službeni dolžnosti. ${ }^{15}$ Čeprav o Bachovi religioznosti ne more biti dvoma, je bilo prenehanje komponiranja religioznih del z Bachove strani - povzeto prosto po Eggebrechtu -zgolj enostranska prekinitev službenih obveznosti.

Pritožba zaradi spremljanja kongregacijskega petja in izpad kantat za leto 1717 sta le dva slučajno izbrana drobca za ponazoritev nejasnosti in dvoumnosti glede Bachove življenjepisne faktografije, dvoumnosti, ki jih marsikateri prikaz mojstrovega življenje že zaradi obsega ne more podrobneje prikazovati in reševati. Vendar pa je iz prikazanih dveh primerov razvidno, da privede podrobno branje primarnih virov v zvezi $z$ Bachovim življenjem pogosto do različnih in celo nasprotujočih si dejstev, ki sestavljajo njegovo biografijo, kot dopušča tudi iskanje in celo ugibanje različnih razlogov zanje. Če gledamo pobliže, je Bachova biografija, se pravi razpravljanje o Bachovem življenju, razmeroma zapleteno, saj je iz razpoložljivih preostalin, čeprav so številne, težko sestaviti tako dokončno faktografsko celoto, da ne bi dopuščala dvomov. Vendar pa to ni posebnost življenjepisa J. S. Bacha. Rekonstruiranje katere koli življenjske poti, tudi življenjske poti najneznatnejšega nemškega kantorja, bi privedlo do dilem, kot jih je mogoče videti ob natančnejšem pogledu v Bachovo življenje.

Dejstvo, da so razprave o Bachovem življenju tako številne in da je bilo s področja Bachove biografije napisano toliko, da je že samo Bachovo življenje lahko tema dolgoletnega študija, dolguje svoj obstoj Bachovi slavi, vsesplošnemu prepričanju, da je bil Bach izredna osebnost; a Bachov življenjepis sam po sebi ne kaže posebnosti, ki bi bile same zase kot zgodovinske partikularnostiv svoji enkratnosti vredne zgodovinskega spominjanja. Bachovo življenje je gledano s tega stališča le primer življenja glasbenika $v$ nemškem protestantskem okolju prve pol. 18. stol. ${ }^{16}$

\section{Osebnoizpovedno in osebno}

Ob tem, da Bachovo življenje v svoji partikularnosti ni bilo nič posebnega, pa se nujno zastavlja vprašanje, kakšno zvezo ima to z njegovo glasbo, prepoznano kot posebno in kot nenadkriljiv dosežek prve pol. 18. stol. Zunanja zveza je očitna že na prvi pogled: Kot kaže Bachov življenjepis, so mnoge njegove kompozicije nastale bodisi po službeni dolžnosti, bodisi po naročilu, ali pa zato, ker je vedel, da bo skladbo, ki jo je nameraval izdelati, kot službujoči glasbenik prej ali slej tudi uporabil, se pravi izvedel. V njegovem opusu so sicer tudi dela, katerih nastanek ni pojasnjen, kot tudi dela, za katera se zdi, da jih je pisal zgolj kot skladatelj, se pravi brez kakega razvidnega namena ${ }^{17}$ vendar je za slednja mogoče predpostaviti, da bi mu objavljena mogla prinesti reputacijo v najširšem smislu, česar bi se lahko zavedal tudi sam. Bachov opus se kaže tako kot odraz njegove življenjske poti oz. kot glasba, ki je bila trdno zasidrana v stvarnih potrebah njegovega okolja, kar lahko razumemo tudi tako, da so bili vzgibi za nastanek njegovih skladb zunanji oz. da so nastajale iz pobud zunaj njega samega.

15 Eggebrecht, H. H., Bach-wer ist das?, str. 158.

16 Tako gledanje na Bachovo življenje je splošno prisotno in ga lahko najdemo v priročniški glasbenozgodovinopisni literaturi: Grout, D. J., Palisca, C. V., A History of Western Music, London 1988 (4. izdaja), str. 497.

17 Med taka sodi morda Maša v h, BWV 232; zdi se, da se v kasnejših leipziških letih Bach ni več oziral na neposredne potrebe svojega okolja. Breig, W., nav. delo, stolpec 1422. 
Ob tem spoznanju, razvidnem iz skladateljevega življenjepisa, si je spekulativno mogoče zamišljati, da bi bil Bachov skladateljski opus v drugačnih življenjskih razmerah drugačen: če Bach ne bi bil sprejet na mesto leipziškega kantorja, in sicer potem, ko eden od kandidatov zanj, Chr. Graupner, ni dobil odpustnice svojega delodajalca, drugi, skladatelj $\mathrm{z}$ razvpito slavo G. Ph. Telemann, pa ponujenega mesta ni hotel prevzeti, ker je v tem času dobil, morda celo izsilil večjo plačo pri svojih predstojnikih, ${ }^{18}$ potem Bach leta 1727 najbrž ne bi izvajal svojega Pasijona po Mateju, ${ }^{19}$ brez katerega si njegove glasbene fiziognomije ni mogoče zamišljati. $V$ drugačnih življenjskih okoliščinah bi bil torej Bachov glasbeni opus po obsegu, naslovih, tipih skladb in še čem drugačen. Seveda si je ob teh s stališča objektivnega zgodovinopisja sicer nedopustnih spekulacijah mogoče misliti, da bi bil mojstrov v drugačnih razmerah nastali opus drugačen le na zunaj in da bi njegovo umetniško bistvo ostalo enako. A tudi če pristanemo na tako gledanje, se v zvezi z Bachovim opusom odpira vprašanje razmerja med umetnikom, ustvarjajočim $v$ čisto določenem času svoje življenjske usode, in novonastajajočim delom, se pravi vprašanje, ali so Bachova dela povezana $z$ njim na tak način, da bi bila izpoved njega samega $v$ vsakokratnem življenjskem položaju.

Dejstvo, da so mnoge Bachove kompozicije nastale kot njegovo službeno delo, kaže, da take povezave ni. Bachovih del, kot jih je pisal v različnih obdobjih svojega življenja, srečnejših in manj srečnih, ni mogoče povezovati s tem, kaj je ob njihovem snovanju kot posameznik doživljal in čutil, saj jih je pisal po zunanjih vzpodbudah in te so narekovale tudi njihov glasbeni značaj. Svetli, briljantno radostni značaj kantate Jauchzet Gott in allen Landen, ${ }^{20}$ ki preveva zlasti njena krajna stavka, nima zveze $\mathrm{z}$ Bachovim notranjim življenjem septembra 1730, ko je delo domnevno nastalo, in sicer kot kantata za 15 . nedeljo po prazniku Svete Trojice. ${ }^{21}$ Podobno je mogoče razmišljati tudi ob drugih Bachovih delih, ki jih tako ni mogoče jemati kot osebne izpovedi, ki bi bile primerljive z izpovedmi literarnega lirskega subjekta. Vprašanje, kaj je osebnoizpovedno, je preneseno na področje glasbe sicer težje rešljivo kot na področju vsebinsko določljivejše literature, zlasti lirskega pesništva, ki v prvoosebnosti premore specializirano sredstvo za izražanje in oprijemljivo kazanje osebnoizpovednosti, vendar je o osebnoizpovednosti mogoče stvarno razpravljati tudi v glasbi: ker so Bachove kompozicije nastajale kot naročena dela in ker je tudi velika večina nenaročenih nastala z ozirom na bolj ali manj stvarne možnosti izvedbe, se pravi z ozirom na okoliščine zunaj njega samega, je zanje mogoče reči, da niso osebnoizpovedna, da se njihov avtor v njih ne kaže kot lirski subjekt, ki "govori v času, ki se sklada s časom govorjenega dogajanja ${ }^{22}$ Pretresljivi Pasijon po Mateju torej ni osebnoizpoveden $\mathrm{v}$ tem smislu, da bi bil izpoved določenega človeka $\mathrm{v}$ določenem življenjskem položaju, da bi njegov avtor v njem izpovedoval svojo osebnost $\mathrm{v}$ njeni neponovljivi enkratnosti in trenutnosti. Nasprotno: je pripoved, ki bi jo lahko izpovedal vsakdo, ki je obsojen na življenje. Tako gledanje se povsem sklada s splošnim, tudi v

Gl. zapisnik sej leipziškega mestnega sveta z dne 9. in 22. 4. 1723: Reich, W., nav. delo, str. 57-58; Breig, W., nav. delo, sţolpec 1409.

BWV 244.

BWV 51

Bach-Werke-Verzeichnis. Kleine Ausgabe, izd. A. Dürr in Y. Kobayashi, Wiesbaden, Leipzig, Paris 1998, str. 55.

Kos, J., Očrt literarne teorije, Ljubljana 1996, str. 95. 
priročniški literaturi razširjenim spoznanjem, po katerem je glasba 17. in prve pol. 18. stol. predvsem prikaz afektov. ${ }^{23}$

Vendar pa je že ob površnem srečanju z Bachovo glasbo očitno, da je zelo izrazita in dobro razpoznavna; kompozicija, kakršna je npr. uvodni koralni zbor v Pasijon po Mateju, je s svojo vzvišeno trpkostjo, veličino, povezano s kompozicijskotehnično zapletenostjo, in dramatičnostjo tako izrazita in značilna za svojega avtorja, da je nikakor ne bi bilo mogoče pripisati komu drugemu. Podobno je tudi $z$ večino drugih mojstrovih del, čeprav ne z vsemi, saj so mnenja o avtorstvu nekaterih njemu pripisanih kompozicij deljena. Ni dvoma, da je Bachova glasba razločno razpoznavna in v tem smislu tudi zelo osebna. Ali je to spoznanje v nasprotju s sodbo, da ni osebnoizpovedna? Na prvi pogled bi se lahko zdelo, da je tako; vendar je treba poudariti, da značilnost osebnega, individualnega ni mogoče enačiti z osebnoizpovednostjo: Osebnost, individualnost Bachove glasbe, čeprav zelo izrazita, je neodvisna od tiste doživljajske trenutnosti, s stališča katere edino govori osebnoizpovedni subjekt.

\section{J. S. Bach v očeh svojih sodobnikov: Scheibe in Birnbaum}

Ob razmišljanju o osebnosti, individualnosti Bachove glasbe je zanimivo in pomenljivo, da so se je zavedali že njegovi sodobniki, čeprav so jo različno ocenjevali. To je razvidno tako iz priložnostnega Matthesonovega zapisa o Bachu kot tudi iz znane polemike o kompozicijah leipziškega kantorja, ki sta jo vodila J. A. Scheibe in J. A. Birnbaum. V prvi pol. 18. stol. je imela odsotnost glasbene javnosti, se pravi splošnega in javnega zanimanja za glasbo samo po sebi, med drugim za posledico tudi to, da so bila javna izrekanja sodb o glasbi razmeroma redka. Da je bil Bach še za življenja deležen kritiške obravnave, je treba med drugim pripisati tudi dejstvu, da je bil razmeroma poznan zaradi svojega položaja kantorja na enem od najvidnejših mest; hkrati pa je mogoče njegovo opaženost videti kot kazalec njegove razpoznavnosti.

Prva javno izrečena in ohranjena izjava o Bachu je zapis J. Matthesona iz leta 1717, v katerem pravi, da je videl nekatera dela weimarskega organista Bacha, tako cerkvena kot orgelska, ki so narejena tako, da je treba moža visoko ceniti. ${ }^{24}$ Matthesonova izjava je kratka in priložnostna, zato je izbranim besedam težko točno določiti pomen, še zlasti, če upoštevamo Matthesonovo znano gostobesednost. A uporabljeni izraz "beschaffen" je mogoče razumeti v širšem pomenskem obsegu kot zgolj "biti narejen" ali "biti ustvarjen": razlagati ga je mogoče tako, da meri na glasbena dela v njihovi celokupni umetniški podobi. Zdi se, da Mattheson leta 1717 v Bachovih delih ni videl le vzorno izdelanih skladb, pač pa da je $v$ njih razpoznal tudi izrazit glasbeni svet in izrazite osebnostne poteze.

Brez dvoma pa je Bachove osebnostne poteze videl njegov kritik Scheibe, ki bi mu težko pripisali, da ni dojel Bachove umetnosti, čeprav jo je zavrnil. Če ob branju Scheibejevega spisa, ki ga je objavil v svoji publikaciji Critischer Musicus leta 1737, ${ }^{25}$

23 Grout, J. A., Palisca, C. V., nav. delo, str. 351

24 Mattheson, J., Das beschützte Orchestre, Hamburg 1717: "...die gewiß so beschaffen sind, daß man den Mann hoch estimieren muß." Povzeto po: Reich, W., nav. delo, str. 39.

Besedilo je med drugim objavljeno v delu: Reich, W., nav. delo, str. 135-136. 


\section{MUZIKOLOŠKI ZBORNIK • MUSICOLOGICAL ANNUAL XXXVI}

odmislimo vrednostne oznake oz. negativne pomenske odtenke uporabljenih izrazov in spregledamo ironični zaključek, da Bachov obilni trud ni obrodil nikakršnega sadu, dobimo verno podobo Bachove umetnosti. Scheibe je v svojem napadu imenoval prav tisto, kar je za Bachovo umetnost tako značilno. ${ }^{26}$ Bachova glasba naj bi bila po Scheibeju v svojem bistvu težka in prekomerno, nejasno in brez potrebe zapletena in celo zmedena; $s$ tem naj bi ji bilo odvzeto glasbeno naravno, glasbena lepota pa prekrita z vse preveliko umetelnostjo. ${ }^{27}$ Scheibejev opis bi se prav lahko nanašal na basovsko arijo Mache dich, mein Herze, rein iz Pasijona po Mateju, ${ }^{28}$ ali pa na obe sicer zelo različni ariji iz kantate Ich will den Kreuzstab gerne tragen, ${ }^{29}$ ariji, kjer je solistični glas, čeprav nosilec besedila, tematsko enakovreden del zapletenega kontrapunktskega sklopa. A tudi uvodni koralni zbor Pasijona po Mateju, če se še enkrat povrnemo k njemu, lahko prav dobro označimo $s$ parafrazo Scheibejevih besed: njegova kompozicijska zapletenost, preobloženost se zdi povezana z njegovim morda celo nekoliko grozljivo temnim značajem, ki je močno oddaljen od težnje po všečnosti in dopadljivosti. Imenovane Bachove skladbe, kot tudi mnoge druge, so bile v očeh Scheibeja, katerega kritika se v estetski literaturi razumeva kot pogled s stališča idealov razsvetljenstva in t.i. galantnega sloga ${ }^{30}$ nekaj čisto drugega kot sočasna modna italijanska glasba, kot jo lahko vidimo tudi v delih njenega najvidnejšega propagatorja G. Fr. Händla, pri katerem so zapletene kontrapunktske konstrukcije vedno tako plastično oblikovane, da poslušalec ni v dvomu glede hierarhičnega odnosa med hkrati potekajočimi glasovi. Scheibe v nadaljevanju Bachu očita, da kot spreten organist sodi po svojih igralnih zmožnostih tudi druge, zaradi česar so njegove kompozicije zelo težke; od izvajalcev, tudi pevcev, zahteva, da delajo isto, kar dela na instrumentu s tipkami sam. Tudi s tem je Scheibe dobro opisal eno od razpoznavnih lastnosti Bachove umetnosti: doslednost, s katero sledi sleherna Bachova skladba neizprosni zakonitosti, logiki glasbenega razvoja, ne oziraje se na to, ali je pisana za tipke, solista $z$ ansamblom, zbor, ali pa je izvajalsko nedoločena.

Kot je znano, je leta 1738 Scheibeju odgovoril J. A. Birnbaum, takrat docent retorike na leipziški univerzi in Bachov prijatelj. ${ }^{31}$ Iz njegovega obširnega spisa, objavljenega $\mathrm{v}$ leipziški periodični publikaciji Musikalische Bibliothek, ${ }^{32}$ je razvidno, da je tudi on prepoznal značilne črte umetnosti svojega someščana. Birnbaumov glavni argument, $s$ katerim zavrača Scheibejevo kritiko, je, da je Bachova glasba urejena, brez napak, kar pomeni, da ji ni mogoče ničesar očitati. Scheibejevi očitki, da je nejasno zapletena, bi bili torej upravičeni, če bi lahko dokazal, da je neurejena in da izkazuje napake. A teh ni, in zato Bachova glasba tudi ne more biti nenaravna. Pojma napake v Birnbaumovem spisu seveda ne smemo razumeti v šolskem, učbeniškem smislu; odsotnost napak v Bachovem

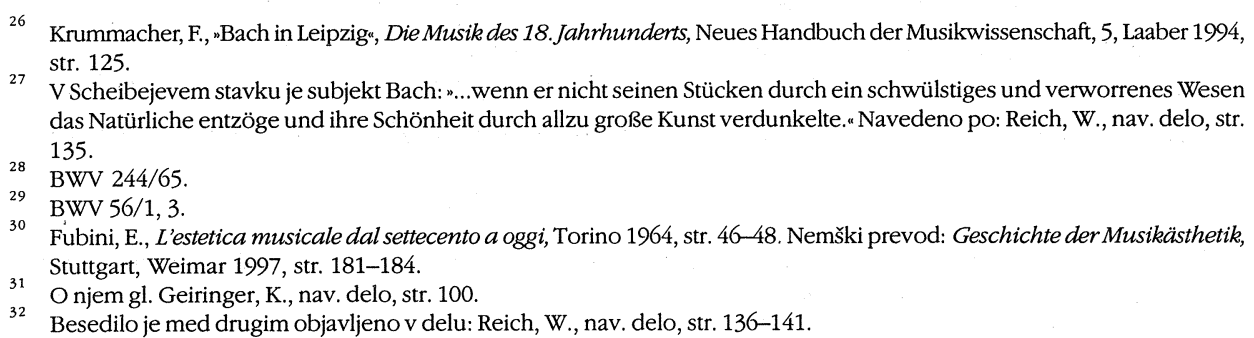


kompozicijskem stavku je pri Birnbaumu sopomenka za logičnost glasbenega poteka, za nujnost takšnih in ne drugačnih kompozicijskih rešitev in izpeljav. Birnbaumovo pisanje velja za dobronameren, vendar Bachovemu geniju nedorasel poskus obrambe pred Scheibejevim napadom, še zlasti zato, ker je izrazil prepričanje, da zasluži Bach enako slavo kot njegov sodobnik Graun. ${ }^{33}$. Vendar pa pozorno branje Birnbaumovega teksta kaže, da je tudi on prepoznaval svojskost leipziškega kantorja. To je med drugim razvidno iz njegovega opisa Bachovega kontrapunkta, ki prepričljivo kaže mojstrovo glasbeno fiziognomijo: glasovi se na občudovanja vreden način prepletajo, vendar brez najmanjše zmedenosti; zdaj se gibljejo vzporedno, zdaj drug proti drugemu, ko je potrebno, pa oboje hkrati; drug od drugega se oddaljujejo in se ob pravem času zopet ujamejo; drug pred drugim bežijo in drug drugega lovijo; vse to pa se po Birnbaumovem mnenju dogaja brez najmanjše nepravilnosti. ${ }^{34}$

\section{Zgodovinski in kanonizirani Bach}

Misel, da so bili Bachovi sodobniki s premalo izraženim priznanjem krivični do njegovega genija, je prenos kasnejših gledanj in vrednotenj na Bachovo dobo. Bachovo okolje je vedelo za svojskost njegove glasbe; a kot je bilo že nakazano, je bil v prvi pol. 18. stol. ob odsotnosti glasbene javnosti sam ustroj glasbenega življenja tak, da ni dopuščal in omogočal pojava genialnega posameznika. Ponovno oživljanje Bachove glasbe kot proces, v katerem je iz zgodovinskega Bacha v zavesti glasbene javnosti 19. stol. začela nastajati podoba nenadkriljivega leipziškega glasbenega genija, je prineslo s seboj tudi posege $\mathrm{v}$ Bachovo življenjepisno podobo in posege $\mathrm{v}$ njegov glasbeni opus.

Tak poseg je bila pravzaprav že ureditev njegove zapuščine. Kot je znano, je Bach v kasnejših leipziških letih težil k ureditvi svojega opusa; zdi se, kot da bi mu želel dati končno podobo in ga določiti. To je razvidno med drugim iz zasnavljanja kompozicij v okviru zbirk: Umetnost fuge, Glasbeno darilo itd., pa tudi v tem, da je že obstoječe kompozicije družil v zbirke, o čemer pričajo zlasti ciklusi kantat in izdaje klavirskih del klavirskih v pomenu, kot ga je izraz imel v njegovem času - pod naslovom Klavierübung. Vendar je bil Bach, če upoštevamo njegovo življenje v celoti, predvsem praktični glasbenik, ki glasbe ni le pisal, pač pa jo je bil dolžan tudi izvajati. Smisel njegovega kompozicijskega dela je bil torej predvideni glasbeni dogodek, v katerem je bil glavni aktant največkrat on sam. Prav zaradi tega njegov opus ob koncu njegovega življenja ni bil urejena, zaključena in določena vrsta kompozicij. Kot je razvidno iz prebiranja nove izdaje seznama Bachovih del, ${ }^{35}$ se je v desetletjih v njegovi skladateljski delavnici nabralo marsikaj: poleg zaključenih opusov, kakršen je bil npr. Dobro temperirani klavir I, suite, partite itd. tudi priredbe lastnih del, zlasti tistih, za katere je presodil, da jih v obliki, $v$ kakršni so obstajala, ne bo mogel več izvajati; ${ }^{36}$ različne verzije istih kompozicij oz. predelave starejših skladb; priredbe tujih del; nedokončane kompozicije; dela tujih skladateljev oz. skladbe $z$ nepojasnjenim avtorstvom. Poleg tega so se mnoge Bachove

33 Krummacher, F., nav. delo, str. 127; Fubini, E., nav. delo, str. 48.

34 Povzeti odlomek je objavljen v delu: Reich, W., nav. delo, str. 138-139.

35 Gl. op. 21.

Krummacher, F., nav. delo, str. 127. 
skladbe ohranile le v prepisih njegovih sodobnikov ali neposrednih naslednikov. Da bi bil njegov opus dostopen in izvedljiv, ga je bilo potrebno urediti, določiti, dati prednost eni od različnih verzij, dela poimenovati in na določeni način razvrstiti. A urejevalno delo je nujno poseglo tudi v samo glasbo: posamične kompozicije je podredilo določenemu razumevanju in pojmovanju, včasih takemu, kakršnemu so bile prvotno tuje.

Kot primer lahko navedemo tako imenovani drugi del zbirke Dobro temperirani klavir. Kot je znano, je Bach leta 1742 dokončal čistopis zbirke, ki je bila zasnovana tako kot njegova dvajset let mlajša zbirka $z$ naslovom Dobro temperirani klavir (Das Wohltemperierte Klavier); sam ji ni dal nobenega imena. ${ }^{37}$ A zbirka je vsesplošno poznana kot Dobro temperirani klavir II. Gotovo je, da je bilo že iz praktičnih razlogov mlajšo vrsto preludijev in fug potrebno poimenovati in izbrano poimenovanje se je zbirki dobro prilegalo, saj je enako zasnovana kot dvajset let starejša. Toda če smo zgodovinsko natančni, se pravi, če skušamo videti stvari takšne, kot so v svojem okolju dejansko bile, moramo priznati, da je izbrano ime zbirki dodano; $v$ določenem smislu ji je celo vsiljeno, saj napeljuje na misel, da je Bach zbirko zasnoval kot nadaljevanje svojega Dobro temperiranega klavirja. Zbirko je sicer mogoče obravnavati kot nadaljevanje one iz leta 1722 in mogoče jo je primerjati $\mathrm{z}$ njo; a legitimnost take primerjave je utemeljena $\mathrm{v}$ svobodi glasboslovnega raziskovanja, ne pa v dejstvu, da bi Bach sam zasnoval mlajšo zbirko kot nadaljevanje starejše. Hipotetično si je možno predstavljati, da je dvajset let mlajša zbirka dobila svojo podobo iz drugačnih nagibov kot starejša, kar bi pomenilo, da bi jo bilo treba gledati in obravnavati iz drugačnih izhodišč.

Tudi v primeru drugih Bachovih nenaslovljenih del je njihovo naslavljanje ali zvrstno določanje naknadni poseg $\mathrm{v}$ mojstrov opus. Bachove kantate kot tudi kantate drugih protestantskih mojstrov 17. in 18. stol. so nekaj čisto drugega kot kompozicije, ki so se v 18. stol. dejansko imenovale kantata, in celo pri tistih Bachovih kantatah, ki so nastale po besedilih E. Neumeistra, je tako imenovanje upravičeno le zaradi Neumeistrove uporabe izraza. ${ }^{38}$ Problematičnost razumevanja ustreznih Bachovih kompozicij v okviru pojma kantata je zlasti v tem, da je nekatere kompozicije tako poimenoval sam, ${ }^{39}$ nekatere so tako poimenovali njegovi neposredni nasledniki, ${ }^{40}$ medtem ko so mnoge ustrezne kompozicije ostale z Bachove strani zvrstno neopredeljene ali pa iz popisa Bachovih del, bodisi novega bodisi starega, ni razvidno, ali jih je tako poimenoval sam ali ne. ${ }^{41}$ Razlika med tistimi skladbami, ki jih je Bach sam gotovo pojmoval kot kantate in onimi, ki jih ni tako poimenoval, je s tem zabrisana. Gledano s strokovnega stališča je razumevanje tistih Bachovih del, ki so se v njegovem času največkrat imenovala kar Kirchenstück, ${ }^{42} \mathrm{v}$

37 Geiringer, K., nav. delo, str. 298.

38 Gl. faksimile naslovnice izdaje besedil E. Neumeistra z uporabo izraza kantata: Sämtliche von Johann Sebastian Bach vertonte Texte, Leipzig 1974, str. 292.

BWV 212: "Cantate burlesque (Kmečka kantata).

40 BWV 211, gl. Schmieder, W., Thematisch-systematisches Verzeichnis der Werke Johann Sebastian Bachs, Leipzig 1976, str. 284 .

41 Naključno izbrano delo je BWV 144, Nimm, was dein ist, und gehe hin, ki je v starejšem Schmiederjevem popisu (gl. op. 40) označeno kot "Kantate (Concerto) am Sonntag Septuagesimae", v novem, Dürrovem pa le kot "Kantate zum Sonntag Septuagesimae. Iz popisov ni razvidno, kaj je napisano na avtografu, če sploh nosi kak naslov, in zakaj jev starejšem popisu delo označeno kot " nconcerto".

42 Breig, W., nav. delo, stolpec 1476 
okviru pojma kantata vprašljivo in zdi se, da sodobni strokovni svet le nerad sprejema na znanje dejstvo, da ustaljenega poimenovanja ne bo več mogoče spremeniti. Podoben primer kot kantate so Bachovi oratoriji, ki po svoji funkciji niso mogli biti oratoriji, čeprav so bile tri tovrstne kompozicije poimenovane tako z Bachove strani. ${ }^{43}$

Podobna problematika se kaže pri poimenovanju posamičnih orgelskih kompozicij tipa preludij / fantazija / toccata in fuga. Iz popisa Bachovih del ni razvidno, ali so ustaljena, redoma navajana in uporabljana imena Bachova, ali so prisotna zgoljv zgodnjih prepisih, ali pa so bila ustreznim delom dodana šele ob ureditvi Bachovega opusa. ${ }^{44}$ Znamenita "dorska" toccata in fuga je v starejšem popisu Bachovih del označena kot "Präludium (Toccate) und Fuge (Dorisch) $4{ }^{45}$ v novem pa kot "Toccata und Fuge in d". ${ }^{46}$ Delo je ohranjeno le v prepisih, a niti iz mlajšega niti iz starejšega popisa ni jasno, kako je kompozicija $v$ samih prepisih pravzaprav naslovljena. Soroden primer je slovita Toccata in fuga $\mathrm{vd}{ }^{47}$. ki je v starejšem seznamu označena kot "Toccata d-moll “, ${ }^{48} \mathrm{v}$ novem kot "Toccata in $\mathrm{d}^{4},{ }^{49} \mathrm{v}$ Die Musik in Geschichte und Gegenwart pa kot "Toccata und Fuge d-moll.$^{50} \mathrm{~V}$ primeru te Bachove skladbe bi lahko razmišljali, da ima v tretji varianti naslova izraz toccata drug pomen kot v prvih dveh: prvič bi lahko meril na tip kompozicije, pri katerem se improvizacijski deli izmenjujejo s fugami, drugič pa na toccatni značaj improvizacijskih delov kompozicije..$^{51}$

Primer razumevanja Bachove glasbe v smislu pozneje nastalih pojmov je mogoče videti tudi $v$ poimenovanju posamičnih kompozicij z oznakami njihovih tonalitet. Tako imajo npr. orgelske kompozicije tipa preludij in fuga ob sebi kot del naslova običajno tudi navedbo ustrezne tonalitete. Vendar Bach svojih kompozicij, kolikor je mogoče soditi iz obeh seznamov Bachovih del, starejšega in mlajšega, ni označeval s tonalitetami, zlasti pa jih ni poimenoval $z$ izrazi dur ali mol, ki jih verjetno ni uporabljal. Slednje je razvidno iz njegovega uvoda v Dobro temperirani klavir I, kjer izrecno pravi, da so preludiji in fuge komponirani na vseh "tonih", in sicer tako, da imajo ti nad seboj bodisi ut, re, mi, se pravi zaporedje dveh velikih sekund, ali pa re, mi, fa, to je zaporedje velike in male sekunde. ${ }^{52}$ Bachu so tonalitete torej "toni", postavitve na posamične tone, ki se poleg tega razlikujejo tako, da imajo nad izhodiščnim tonom bodisi veliko ali pa malo sekundo. To gledanje in ta terminologija sta blizu razumevanju, kot ga lahko vidimo priJ. Matthesonu, J. Waltherju, ${ }^{53}$

43 Breig, W., nav. delo, stolpec 1490.

44 BWV 548, Preludij in fuga v e, ima npr. dva ločena naslova, ne pa enega skupnega: »Praeludium pedaliter pro Organo in na ustreznem mestu "Fuga“. Faksimile: Johann Sebastian Bach. Neue Ausgabe sämtlicher Werke, IX/2, Die Notenschrift Johann Sebastian Bachs. Dokumentation ihrer Entwicklung, izd. Y. Kobayashi, Bärenreiter 1989, str. 128-129.

45 BWV 538. Schmieder, W., nav. delo, str. 416.

46 Bach Werke Verzeichnis. Kleine Ausgabe, str. 316.

47 BWV 565.

48 Schmieder, W., nav. delo, str. 428

49 Bach Werke Verzeichnis. Kleine Ausgabe, str. 324.

50 Breig, W., nav. delo, stolpec 1456.

51 Pri severnonemških mojstrih poznega 17. stol. pomeni toccata skoraj isto kot preludij in fuga: Caldwell, J., "Toccata", The New Grove Dictionary of Music and Musicians, 19, London 1980, str. 19. - Nejasno je tudi poimenovanje BWV 572: v starejšem popisu je ta orgelska kompozicija z impozantnim srednjim delom označena kot "Fantasie G-dur" (Schmieder, W., nav. delo, str. 430), v mlajšem pa kot "Pièce d'Orgue in G" (Bach Werke Verzeichnis. Kleine Ausgabe, str. 326). Od kje razumevanje te, le v prepisih ohranjene kompozicije kot fantazije?

52 Faksimile: Johann Sebastian Bach. Neue Ausgabe sämtlicher Werke, IX/2, str, 87.

53 Mattheson, J., Dervollkommene Kapellmeister, Hamburg 1739, I, 9, str. 60-68; faksimile: Documenta musicologica, Erste Reihe: Druckschriften-Faksimiles, V, izd. M. Reimann, Bärenreiter 1995; Walther, J., Musikalisches Lexikon, Leipzig 1732, str. 408-418; faksimile: Documenta musicologica, Erste Reihe: Druckschriften-Faksimiles, III, izd. R. Schaal, Bärenreiter 1953. 
zlasti pa sta blizu Rameaujevim tehtnim in globoko utemeljenim izpeljavam. ${ }^{54}$ Kazalec, da se tonalnost Bachove glasbe največkrat brez ustreznih opozoril razumeva s poznejšimi pojmovanji, je tudi dejstvo, da se običajne monografije o Bachu ne ukvarjajo z vprašanjem, kakšen je bil teoretski pogled na glasbo v Bachovem okolju; to tudi pomeni, da se ne sprašujejo, s katerimi pojmi in termini je Bach sam razumeval glasbo svojega časa, vključno $s$ svojo lastno. Ustaljeno tonalno oz. tonalitetno razumevanje Bachove glasbe temelji torej na pojmovanjih, ki so nastala šele kako stoletje po Bachovem času. Vendar je treba ob tem poudariti, da se novi seznam Bachovih del odpoveduje oznakam dur in mol, kar kaže na zavest o njihovi zgodovinski omejenosti kot tudi zgodovinski omejenosti z njima združenih pojmov.

V zvezi s tem je zanimiv primer že omenjene "dorske "Toccate in fuge v d. ${ }^{55}$ Starejši popis Bachovih del imenuje to delo "dorsko", mlajši pa jo označuje le z izhodiščnim tonom d. ${ }^{56}$ Razlog za oznako "dorska" je v dejstvu, da ohranjeni zapisi te kompozicije nimajo začetnega predznaka b. "Dorskih" kompozicij v tem smislu je v Bachovem opusu več: tak je npr. prvi stavek kantate Wer nur den lieben Gott läßt walten, ${ }^{57}$ katerega tonalno središče je postavljeno na c, skladba pa ima le dva, ne tri nižaje; taka je večina stavkov v prečudoviti, v širokem razpoloženjskem loku izpeljani kantati Ich hatte viel Bekümmernis, ${ }^{58}$ ki imajo en nižaj manj, kot bi glede na tonalno središče pričakovali (stavki v c in Es imajo dva nižaja, stavki v $\mathrm{f} \mathrm{tri).} \mathrm{Vendar} \mathrm{pa} \mathrm{nastopata} \mathrm{tona} \mathrm{b} \mathrm{in} \mathrm{h}$ v "dorski" Toccati in fugi $\mathrm{v}$ d skladno s tonalnim razvojem kompozicije in tako je, zdi se, tudi drugod, kjer je število nižajev manjše od pričakovanega. V čem je torej dorskost imenovane, le v prepisih ohranjene kompozicije; čigav je izraz dorski; je izraz zanjo primeren, je zgolj priložnostni razlikovalni vzdevek brez globljega pomena ali pa oznaka, ki meri na sicer malo verjetni drugačni tonalni ustroj kompozicije? Po novem seznamu Bachovih del je izraz dorski v primeru te kompozicije zavajajoč. ${ }^{59}$

Kot je bilo omenjeno, je v Bachovem opusu tudi mnogo variant in priredb lastnih kompozicij, pravzaprav avtoparodij. Med mnogimi tako nastalimi skladbami lahko omenimo kantato Erhöhtes Fleisch und Blut, nastalo kot predelava posvetne kantate Durchlaucht'ster Leopold. ${ }^{60}$ Koncerti za čembalo in godala oz. orkester s kontinuom ${ }^{61}$ so leipziške predelave lastnih koncertov, narejene večinoma za Collegium musicum in njegove sredine oz. petkove glasbene popoldneve oz. večere v Zimmermannovi kavarni in drugje. ${ }^{62}$ Tako je npr. Koncert za čembalo in orkester $\mathrm{v} \mathrm{F}^{63}$ predelava četrtega od Brandenburških koncertov v G. ${ }^{64}$ Čeprav se Bachovi koncerti za čembalo in godala oz. orkester zapostavljajo za koncerte, iz katerih so nastali, zgodovinsko gledano ni pravega

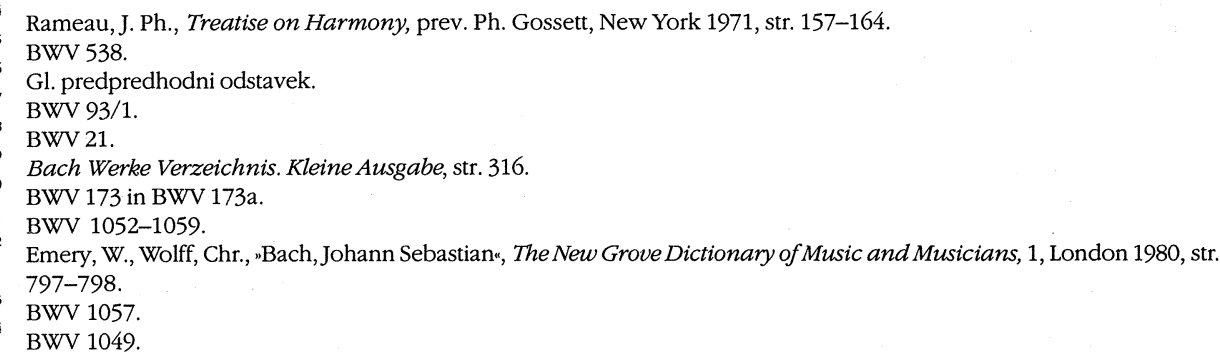


razloga za njihovo drugačno vrednotenje: oboji so delo istega mojstra, oboji so nastali v določenem času na pobudo določenih potreb in oboji so bili v času svojega nastanka dokončna dela. Tako bi lahko razmišljali tudi v primeru drugih Bachovih priredb, parodij in predelav, celo v primeru tistih, kjer je bolj očitno, da je skladatelj drugo verzijo imel za dokončno, kot na primer pri dvojih verzijah nekaterih njegovih invencij in sinfonij. ${ }^{65} \mathrm{Pri}$ presojanju in vrednotenju Bachovih predelav se kažejo teorije o istovetnosti glasbenih del N. Goodmanna, čeprav nastale znotraj glasbenofilozofskih razmišljanj in ne zgodovinopisnih, povsem upravičene in aplikabilne. ${ }^{66}$

Iz prikazanega je mogoče povzeti: Bachov opus brez ureditve njegove zapuščine večinoma ne bi bil niti dostopen niti izvedljiv; hkrati zureditvijo, ki je potekala v določenem zgodovinskem obdobju, pa je Bachovo glasbeno delo dobilo konotacije, ki jih samo zase v svojem okolju ni imelo. Poleg tega je glasbeno življenje 19. in 20. stol., sledeč lastnemu vrednotenjskemu videnju, nekatera Bachova dela povzdignilo, jih postavilo v ospredje, druga pustilo v ozadju. $Z$ vsem tem je nastal razkorak med zgodovinskim Bachom in njegovo oživljeno podobo. Bachova glasba, kot je obstajala v svojem času in okolju, tako ni povsem zamenljiva s tistim glasbenim opusom, ki je izvzet iz razmer svojega časa in identificiran $z$ imenom J. S. Bacha postal glavni temelj evropskega glasbenega kanona.

\section{Bachova podoba $v$ glasbenem zgodovinopisju}

Jedro nepregledno obsežne literature o Bachu predstavljajo velike monografije, ki so jih ustvarili N. Forkel, ${ }^{67}$ Ph. Spitta, A. Schweitzer, K. Geiringer, M. Boyd ${ }^{68}$ in drugi, dela, ki skušajo čim bolj celovito prikazati Bachovo osebnost in njegovo glasbeno delo. Bachovo Življenje in njegov glasbeni opus sta tudi obvezna tema sleherne glasbene zgodovine, bodisi obsežne ali zgoščene, splošne ali specialne. Ob študiju literature o Bachu se pogosto zastavlja vprašanje: Je razpravljanju o Bachu uspelo prikazati njegovo svojskost? Ali je bilo razpravljanje o Bachu tisto, ki je privedlo do jasne zavesti o izrednosti njegovega genija, ali pa je, nasprotno, razpravljanje o Bachu posledica že obstoječega dojetja njegovega veličine? Kompleksnost pojava oživitve Bachove glasbe in vsebinska in stališčna raznolikost literature o njem kažeta, da bi bila odločitev za eno od obeh nakazanih možnosti ob popolni izključitvi druge preveč ostra in s tem enostranska; primerneje je, če se v zvezi z imenovano problematiko vprašamo takole: Kako se v glasbenozgodovinopisni literaturi prikazuje Bachovo delo, v čem se izpostavlja in kako se utemeljuje njegova svojskost?

Za vzorčni primer, ob katerem je mogoče pretresati navedeno vprašanje, lahko izberemo obravnavo Bachovega zvočno sijajnega Magnificat v $\mathrm{D}^{69} \mathrm{v}$ The New Oxford History of Music, najobsežnejšem obstoječem glasbenozgodovinopisnem pregledu. ${ }^{70}$

BWV 772-801.

Kratka predstavitev Goodmanovih teorij (Goodman, N., Languages of Art: An Approach to a Theory of Symbols, Oxford 1996) je dostopna v delu Goehr, L., The Imagenary Museum of Musical Works, Oxford 1992, str. 21-24.

${ }_{68}$ Forkel, N., ÜberJ. S. Bachs Leben, Kunst und Kunstwerke, Leipzig 1802. (Nova izdaja: Kassel itd. 1982.)

68 Boyd, M., Bach, London 1983; za ostale navedene monografije gl. op. 1 in 10.

69 BWV 243

70 Steinitz, P., "German Church Music", The New Oxford History of Music, V, London 1975, str. 608. 


\section{MUZIKOLOŠKI ZBORNIK • MUSICOLOGICAL ANNUAL XXXVI}

Bachovo delo je obravnavano v sklopu drugih predhodnih in Bachu sočasnih uglasbitev tega latinskega besedila, ki so jih ustvarili nemški skladatelji v 17. in zgodnjem 18. stol. Izhodišče razpravljanja je glasba sama in obravnavanje posameznih uglasbitev $\mathrm{v}$ časovnem zaporedju njihovega nastanka obvladuje vsebinski tok poglavja do take mere, da ostaja vprašanje o dejanski funkciji besedila $v$ nemškem protestantskem okolju povsem v ozadju, čeprav bi prav to lahko razložilo, zakaj so uglasbitve Magnificat tako redke in zakaj ima Bach le dve oz. eno, če imamo drugo le za različico prve. ${ }^{71}$ O Bachovem delu izvemo, da "skorajda nima šibkega takta", da imajo skoraj vsi stavki obliko z ritornelom, da so ostali stavki zasnovani kot fuge, da so zadnji takti kompozicije izpeljani iz prvega stavka. Pri tem so omenjena nekatera posebno odlična mesta oz. mojstrska uporaba nekaterih kompozicijskih postopkov, tako na primer način, kako se v stavku Fecit potentiam druži fuga s homofonijo.

Če analiziramo izbrani prikaz, lahko ugotovimo: Obravnava Bachovega dela v sklopu del iste oblike drugih skladateljev, med katerimi je Bachovemu delu odmerjeno komaj kaj več prostora kot drugim, je legitimna, zgodovinopisno ustrezna, saj Bachov Magnificat v svojem času, gledano z zgodovinopisnega stališča, ni izstopal, se pravi, da ni imel kakega posebnega položaja, ki bi ga moralo zgodovinopisje zaznati in se mu posvetiti. Vendar pa se iz same obravnave Bachovega Magnificat - če odštejemo vrednotenjske pridevnike, dobljene zgolj preko metode kritiškega presojanja, ne vidi, v čem je drugačno od drugih oz. $v$ čem je tako, da je ena od uglasbitev istega besedila J. Ph. Kriegerja $\mathrm{v}$ primerjavi z njegovo po avtorjevi sodbi bleda, neizrazita. ${ }^{72}$

Do podobnih ugotovitev lahko pridemo tudi pri specialnih zgodovinah, na primer ob branju obsežne Blumejeve zgodovine glasbe nemškega protestantizma. ${ }^{73}$ Kot nakazuje že osnovni okvir razprave, razumeva Blume Bachova dela predvsem na ozadju nemškega protestantizma; to še zlasti velja za korale, trdno zasidrane v religioznem življenju Bachove dobe. Kot je nemški protestantizem vključeval po eni strani razodetje oz. branje božje besede, po drugi strani pa njene razlage, tako se to dogaja tudi v nemški orgelski glasbi in še zlasti Bachovi: s koralom, povezanim $\mathrm{z}$ besedilom oz. njegovo vsebino, se $\mathrm{v}$ glasbi podaja razodetje, lahko tudi njegove razlage; razlage pa so še zlasti prisotne v Bachovih kompozicijskih izpeljavah in s tem, da vsebujejo razlage, so Bachove kompozicije podobne pridigam. Med mnogimi Bachovimi religioznimi temami je prisotna celo unio mystica, ena osrednjih predstav nemške mistike. A Blume se ne ustavlja le pri religioznem ozadju Bachovih orgelskih del; presoja jih tudi v zgodovinskem sosledju. Bachova orgelska glasba je po njegovi sodbi absolutni vrhunec orgelske glasbe sploh, kot so Bachove kantate in pasijoni zanj absolutni vrhunec vsega protestantskega sakralnoglasbenega snovanja. ${ }^{74}$ Blumejev pogled na zgodovino, tj. na duhovnozgodovinsko in umetnostnozgodovinsko dogajanje, je izrazit razvojni in organski pogled: žanri, oblike, stvari nastajajo, se razraščajo, dosegajo vrhunce, upadajo, in med tem ko se izgubljajo v nepomembno, nastajajo druge. V tem smislu vidi Blume Bachovo orgelsko glasbo kot vrhunec razvojne

\footnotetext{
1 Znano je, da je bilo delo namenjeno večernicam prvega božičnega dne v Bachovem prvem leipziškem letu: verzija v Es BWV 243a je bila prvič izvedena na božič 1723; gl. Bach Werke Verzeichnis. Kleine Ausgabe, str. 247.

2 Steinitz, P., nav. delo, str. 608.

3 Blume, F. in drugi, Geschichte der evangelischen Kirchenmusik, Bärenreiter 1965 (2. izdaja).

Blume, F., nav. delo, str. 179.
} 
krivulje. Orgelska glasba Bachovih sodobnikov in učencev je po Blumeju veliko preprostejša, tako kompozicijskotehnično kot "duhovno"; tradicija navezovanja na Bachovo orgelsko glasbo je živela še dalje, na primer tudi v srednjenemških deželah, slednjič se je, po Blumeju, iztekla v delovanju malih in nepomembnih mojstrov. ${ }^{75}$

Blume je primer izredno široko razgledanega avtorja, ne le glasbeno, pač pa tudi kulturnozgodovinsko razgledanega, ki je - primerljivo romanopiscem 19. stol. - zmogel $z$ enim pogledom popisati in premeriti kulturno in glasbeno dogajanje stoletij. Prav ta široki razgled mu je omogočil zaznavanje in opazovanje rastočih in padajočih zgodovinskih krivulj in vrednostne sodbe o njihovih vrhuncih in nižiščih. Argumenti Blumejevih sodb so zasidrani v njegovem poznavanju in videnju stvari: le njegov poznavalski razgled mu omogoča zaznavanje in vrednotenje glasbenorazvojnih krivulj. Z drugimi besedami to pomeni, da temelijo tudi Blumejeva vrednotenja v svojem bistvu na metodi kritiškega presojanja, le da ne izhajajo zgolj iz poznavanja glasbe, ampak iz širokega pogleda na zgodovino duhovnega življenja sploh. Do podobnih zaključkov bi mogli priti tudi ob analitičnem branju številnih drugih glasbenozgodovinopisnih besedil.

\section{Religioznost Bachove glasbe}

Vendar pa dejstvo, da je običajni pogled na Bachovo glasbo glasbenozgodovinopisni, ne izključuje drugačnih pogledov in načinov vrednotenja njene vsebine. Iz marsikaterega pisanja o Bachu izžareva bolj ali manj jasno izraženo prepričanje, da je veličina njegove glasbe v njeni religioznosti; se pravi v tem, da izhaja iz sveta religioznih izkušenj, ki ga razpira tako tudi vsem tistim, ki se ji svobodno prepustijo; prav s tem naj bi se Bachova glasba povzdigovala nad povprečje svoje dobe in prav $\mathrm{v}$ tem naj bi bila tudi njena nedosegljiva veličina. Da je Bachova glasba, v prvi vrsti tista, ki je nastala za protestantsko bogoslužje, zasidrana v svetu nemškega protestantizma, je glasbenozgodovinopisno dejstvo. Tako jo je videl tudi Blume, čeprav iz njegovega pisanja ni razvidno, da bi jo cenil predvsem zaradi tega. Nasprotno pa je religioznost Bachove glasbe kot njeno prvo in bistveno določilo izpostavljena pri nekaterih drugih avtorjih, tako na primer pri A. Schweitzerju. ${ }^{76}$

Za Bachovo izkazovanje religioznosti ni težko najti ponazoril; naslov Orgelske knjižice se konča s posvetilom "najvišjemu Bogu ", ${ }^{77}$ posebno zanimiv pa je v tej zvezi odstavek iz Bachovega spisa o generalnem basu, kjer beremo, da je končni smisel tako generalnega basa kot glasbe sploh "božja slava in krepčilo človeškega duha" ${ }^{78}$ Podobnih primerov, kot sta navedena, je še nekaj, čeprav niso posebno številni. Vendar je treba tovrstne Bachove izjave videti v njihovem zgodovinskem okolju, se pravi v okolju, ki mu je bil novodobni pojem sekularizacije tuj. Gledane s stališča sekulariziranega okolja, so

Blume, F., nav. delo, str. 178

76 Schweitzer, A., nav. delo, str. 152-153; nekatere ekstremne religioznost izpostavljajoče izjave o Bachu so navedene v delu: Eggebrecht, H. H., Bach - wer ist das?, str. 156.

77 Reich, W., nav. delo, str. 40-41; faksimile: Kolneder, W., K-H. Jürgens, J. S. Bach. Lebensbilder, Gustav Lübbe Verlag 1984 , str. 87.

78 "Gottes Ehre und Rekreation des Gemütsw; navedeno po: Reich, W., nav. delo, str. 126; angleški prevod: J. S. Bach's Precepts and Principles For Playing the Thorough-Bass or Accompanying in Four Parts, prev. Pamela L. Poulin, Early Music Series, 16, Oxford 1994, str. 10-11. 
navedene Bachove izjave izjave religioznega človeka; če pa jih razumemo kot izjave leipziškega kantorja iz prve pol. 18. stol. in jih gledamo v sklopu podobnega religioznega izjavljanja v protestantskem okolju, se pokažejo v drugačni luči. Prva od obeh navedenih izjav lahko pomeni zgolj za svoj čas običajno zaključno formulo; prav tako tudi druga izgubi svojo izrecnost, če si zamislimo, da so se v Bachovem okolju, in ne le v njem, mnoge misli javno ubesedovale poudarjajoč povezanost vseh stvari tega sveta $\mathrm{z}$ Bogom in njegovo slavo. ${ }^{79}$ Če bi iskali tovrstno izrekanje religioznosti, bi ga brez dvoma mogli najti kjer koli, in tovrstne izjave so izrekale tudi osebe, katerih siceršnje zadržanje ne bi kazalo njihove posebne religioznosti.

Kot omenjeno, je med avtorji, ki so videli Bacha predvsem kot razlagalca uglasbljanih ali -v primeru orgelskih koralov - s koralno melodijo asociativno povezanih besedil, tudi A. Schweitzer. Po Schweitzerju je z ozirom na Bacha sama definicija glasbe nerazdružno povezana z religioznostjo. ${ }^{80}$ Iz njegove monografije o Bachu, ki izpričuje glasbeniško živ odnos do obravnavanih kompozicij in do vprašanj $v$ zvezi z njimi in je zato ne glede na verjetnost ali sprejemljivost sodb vedno privlačna in zanimiva, veje misel, da je veličina Bachove glasbe prav v tem, da podaja in razlaga vsakokratno religiozno vsebino. Po Schweitzerju so mnoge kompozicijske odločitve, ki se zdijo na prvi pogled nerazumljive, čudne, celo napačne, posledica Bachove težnje po primernem odnosu, primerni uglasbitvi besedila; Bachovih kompozicijskih rešitev, med drugim tistih v njegovih kancionalnih harmonizacijah koralov v kantatah in pasijonih, brez poznavanja besedila in njegovega miselnega okolja tako ni mogoče razumeti. ${ }^{81}$

Najbolj oprijemljivo se Bachov odnos do religioznih besedil kaže na tistih mestih njegovih kompozicij, kjer je dejanske glasbene tvorbe, motive, teme ali kompozicijske postopke mogoče vzporejati s podobami uglasbljanih besedil. Religiozna vsebina besedila naj bi tako na neki način postala glasbena vsebina kompozije, in ta naj bi pričala o globini religioznega doživljanja njenega avtorja. Primerov takega povezovanja, ki ga je mogoče razumeti v smislu figuralike tipa hypotyposis, je v Bachovem opusu brez števila. Nekateri so v svoji namernosti zelo izraziti, drugi manj. A kaj more opisani odnos do besedila povedati o avtorjevi religioznosti, je mogoče ponazoriti $z$ analizo naključno izbranega primera, teme uvodnega koralnega zbora kantate Wachet auf. ${ }^{82}$ Ta šestnajsttaktna tema, ki ima v kompoziciji oblikovno funkcijo ritornela, naj bi po nekaterih ustaljenih razlagah slikala prizor iz Matejevega Evangelija, ${ }^{83}$ na katerega se nanaša besedilo kantate: trkanje oz. pozvanjanje polnočnih zvonov, vznemirjenje prebujenih deklet in njihovo nestrpnost in čuječnost. ${ }^{84}$ Če štejemo tone v motivu prvih štirih taktov, jih je natanko dvanajst: štirje takti v tričetrtinskem taktu dajo dvanajst četrtink, mesto vsake pa je izpolnjeno s punktiranim ritmom; s tem naj bi Bach nakazoval bitje polnočne ure. Naslednji motiv teme naj bi ponazarjal vznemirjenost prebujenih deklet in tretji (od takta 9 dalje) hitenje naproti nebeškemu ženinu. Vse to si je ob poslušanju te Bachove izredno domiselne in

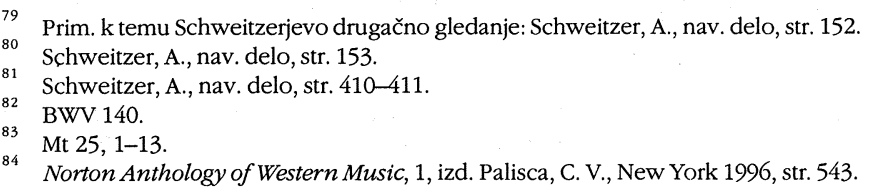


plastične teme kaj lahko predstavljati in sam glasbeni potek opisanim predstavam ne nasprotuje; vsekakor jih dopušča, morda celo vzpodbuja. Vendar se je ob njih treba zavedati naslednjega: Prvič: Kot pri veliki večini sorodnih sklepanj tudi pri tem ni nikakršnega neposrednega podatka, ki bi potrjeval obstoj programa, ki bi torej potrjeval, da je Bachova inspiracija v resnici izhajala iz tako zamišljenih slik. Bach sam svojih kompozicij ni komentiral, vsaj dokumentirano ne. Na odsotnost zgodovinske dokazanosti resničnega programa kaže tudi dejstvo, da je obravnavani ritornelo pri različnih avtorjih različno interpretiran: Schweitzer komentira le prva dva motiva, ki mu predstavljata ženinov prihod spremljajoče zvonenje od vseh strani in prestrašeno prebuditev in hitenje prerivajočih se deklet; Geiringer vidi v drugem motivu veseli nemir prebujenih; za Spitto pa je isti motiv izraz skrivne sreče. ${ }^{85}$ Drugič: Tema kompozicije, ki jo sestavljajo trije izraziti motivi, je v svojem estetskem učinkovanju enovita: drugi motiv je mogoče navezati na prvega, čeprav je povsem drugačen od njega, tretji motiv pa na drugega. Poslušalec, ki dojema jezik evropske glasbe 18. stol., temi lahko sledi in jo lahko sprejema brez kakršnega koli zunajglasbenega pojasnila, kar pomeni, da je prisotnost ali odsotnost zavesti o z njo povezanih zunajglasbenih podobah za njeno glasbeno dojemanje zanemarljiva. Tema sama $z$ ničemer ne nakazuje religioznosti kompozicije - bila bi lahko tudi tema instrumentalnega koncerta. Tretjič: Odsotnost zgodovinskega podatka o obstoju programa za obravnavano skladbo seveda ne pomeni, da Bach pri komponiranju dela ne bi mogel imeti v mislih zunajglasbenih podob, morda prav takih, kot so si jih zamislili razlagalci, saj je bila glasbenoretorična figuralika tipa hypotyposis sestavni del skladateljske poetike Bachovega časa. A tudi če predpostavimo, da je z obravnavano temo Bach dejansko na svoj način slikal sceno iz Matejevega Evangelija, priča to dejstvo izključno le o načinu delovanja njegove glasbene invencije, o njegovi ars inveniendi. Ne more pa dejstvo, da je uporabljal figure hypotyposis, ki jih je izpeljeval iz podob uglasbljanega religioznega besedila, biti argument skladateljeve religioznosti.

Primerov, kakršen je pravkar opisani, je v Bachovem opusu brez števila; v njem so tudi še bolj očitni in nedvomni primeri figuralike hypotyposis, na primer v koralnem preludiju Durch Adams Fall. ${ }^{86}$ Če že ni prav zanesljiva glasbena podoba zvijajoče se varljive kače, je v tem koralu zagotovo prisotna slika usodnega padca: ${ }^{87} \mathrm{v}$ pedalu se ves čas vrstijo skoki navzdol, v glavnem septimni, ki so toliko bolj vpadljivi, ker bi bila z ozirom na običajno, učbeniško predpisano vodenje glasov namesto septimnih skokov vedno možna krajša pot za sekundo navzgor. Bach je v tej kompoziciji uporabil septimne skoke kot motiv, ki vseskozi spremlja potek koralne melodije, in s tem motivom je preludij nenavaden, $v$ primerjavi s siceršnjo glasbo zgodnjega 18. stol. - delo je iz Bachove weimarske Orgelske knjižice - celo drzen. A v dovršeni kompoziciji kot celoti imajo Bachovi septimni skoki ne glede na to, kako je Bach prišel do zamisli, da bi jih uporabil, predvsem estetski glasbeni učinek. Ob tem spoznanju pa dejstvo, da je Bach zamisel kompozicije z glasbenimi podobami padajočih septim izpeljal iz glavne misli besedila koralne melodije, ni več pomembno.

87 Norton Anthology of Western Music, 1, str. 499. 
Z vprašanjem Bachove religioznosti oz. religioznosti njegove glasbe se je pred časom ukvarjal H. H. Eggebrecht, ki je ob nekatera izrazito religiozna razumevanja Bachove umetnosti postavil trezno zgodovinsko podobo, kot jo je imenoval sam. ${ }^{88} \mathrm{~V}$ tem okviru Eggebrechtova razprava ugotavlja, da je tudi glede religioznosti Bachove umetnosti občuten razkorak med zgodovinskim Bachom in njegovo kasnejšo podobo. Eggebrecht je svoj pogled na religioznost Bachove glasbe podal v obliki štirih dejstev: 1. Iz življenjepisa je razvidno, da Bach ni dajal prednosti službenim mestom, ki bi od njega zahtevala komponiranje religioznih del; za leipziški kantorat se je odločil, ker je s tem prešel na boljše delovno mesto. 2. Iz dejstva, da je Bach uglasbljal religiozna besedila, ni mogoče sklepati na njegovo religioznost, saj uglasbljana besedila niso bila njegova, pač pa so jih za dejanske potrebe protestantskega bogoslužja pisali drugi. 3. Tudi dejstvo, da je Bach religiozna besedila uglasbljal tako, da se je oziral na njihovo vsebino, iz katere je izpeljeval posamične glasbene tvorbe, ni dokaz njegove religioznosti; tako postopanje je sodilo $\mathrm{v}$ običajno skladateljsko prakso dobe, bilo je del skladateljskega mojstrstva. 4. Bachova glasba bi lahko bila religiozna po svojih kompozicijskih lastnostih, po svojem stilu; a v tem primeru bi kot religiozno videli Bachovo glasbo v celoti, ne le njegova bogoslužju namenjena dela. Eggebrecht zaključuje z vprašanjem: Ali ni tako videnje Bachove glasbe, da je namreč religiozna, možno šele s s časovne perspektive kasnejšega časa, s položaja, ki pozna drugačno glasbo, glasbo kot osebni izraz govorečega subjekta, glasbo, ki je z ozirom na svojo osebnoizpovednost drugačna tudi v kompozicijskotehničnem pogledu? ${ }^{89}$ Z drugimi besedami: Ali se ne pokaže Bachova glasba religiozna šele tedaj, ko jo iz njenega zgodovinskega okolja prenesemo v kasnejši, sekularizirani čas?

\section{Skrita sporočila glasbenih simbolov}

Čeprav se oddaljuje od razmišljanj o estetskem učinkovanju, sodi iskanje zunajglasbenih izvorov Bachove inspiracije med pomembne teme razpravljanja o njegovi umetnosti. Podobno je mogoče reči tudi za odkrivanje Bachovih glasbenih simbolov in tako kot ob iskanju zunajglasbenih vzporednic $h$ kompozicijskim postopom se tudi ob glasbenih simbolih zastavlja vprašanje: Kaj more odkrivanje glasbenih simbolov v Bachovem opusu povedati o njegovi glasbi? Ali je poznavanje skritih simbolnih sporočil za razumevanje Bachovega genija potrebno? Obstoji povezava med globino Bachove glasbe in njenimi skritimi simbolnimi sporočili?

Glasbeni simbol bi lahko označili kot glasbeno tvorbo ali kompozicijski postopek, ki nosi poleg svojega estetskega učinka sporočilo, ki je razumljivo le v primeru, če se dekodira $v$ določenem, s skladateljeve strani predvidenem znakovnem sistemu. Pojav tretje teme b-a-c'-h v zadnji kompoziciji zbirke Umetnost fuge ${ }^{90}$ je torej glasbeni simbol: poleg tega, da ima svoj estetski učinek, sporoča ime avtorja kompozicije, vendar le, če se imena njenih tonov preberejo v črkovnem znakovnem sistemu. V Bachovem opusu so raznovrstni glasbeni simboli: poleg črkovnih simbolov, kot lahko imenujemo omenjeni primer, še

${ }^{88}$ Eggebrecht, H. H., Bach - Wer ist das?, str. 156-168.

${ }^{89}$ Ustrezni Eggebrechtov izraz je "načini komponiranja, pri katerih je stopila v ospredje psihična občutliivost človeka"; gl. nav. delo, str. 166.

90 BWV 1080/20. 
številčni simboli in številčno-abecedni simboli, tisti, ki jih je mogoče razbrati z ustreznim prevodom številk v črke. ${ }^{91}$ Številčnih simbolov je v Bachovem opusu kar nekaj: v zboru Herr, bin ichs ${ }^{22}$ v Pasijonu po Mateju je vstopov toliko, kolikor je govorečih oseb, se pravi 12, kar pa bi bilo mogoče razumeti tudi kot primer figure hypotyposis. Najbolj znani simboli v Bachovem opusu so številčno-abecedni simboli v koralnih preludijih Wenn wir in höchsten Nöten sein in Vor deinen Thron: Kolorirana oz. parafrazirana koralna melodija ima $\mathrm{v}$ weimarskem preludiju Wenn wir iz Orgelske knjižice ${ }^{93}$ natanko 158 tonov, število, ki je vsota številčnih vrednosti črk Bachovega polnega imena "Johann Sebastian Bach". (Črka A ima vrednost 1, B vrednost 2, C vrednost 3 itd.) Število 158 bi bilo tu lahko zgolj slučajno, a kasnejši, leipziški preludij z istim koralnim napevom, čeprav drugačnim naslovom, ${ }^{94}$ je prav tako mogoče interpretirati v smislu številčno-abecednega simbola. V tej kompoziciji ima glas s koloriranim oz. parafraziranim koralom natančno 41 tonov, kar je vsota številčne vrednosti Bachovega imena v obliki "J. S. Bach", prva fraza parafraziranega korala pa ima številčno vrednost mojstrovega priimka: "Bach" ${ }^{95}$ Zdi se, da je mojster tako v starejšo kot v mlajšo kompozicijo hote skril svoje ime, svoj avtogram. V primeru leipziškega koralnega preludija je domneva še toliko bolj verjetna, ker je to delo najbrž Bachova zadnja kompozicija in morda je oslepeli mojster, ki jo je moral narekovati, to celo slutil. ${ }^{96}$

Pritrditi je treba Eggebrechtovemu stališču, v katerem se je izrecno distanciral od spekulativnega iskanja številčnih simbolov v Bachovem opusu: ${ }^{97}$ Izvajanje številk iz Bachovih kompozicij, njihovo vsakovrstno, včasih prisiljeno kombiniranje in iskanje njihovih skritih sporočil ne oziraje se na glasbeni potek, nima prave zveze z Bachovo glasbo. Obstoj glasbenega simbola je v Bachovem opusu po Eggebrechtovem mnenju verjeten le takrat, ko ga nakazujejo tudi drugi kazalci: ko se tvorba $\mathrm{z}$ domnevnim simbolnim sporočilom pojavi na pomembnem mestu v glasbenem razvoju skladbe, ko se na odločilnem mestu kompozicije sklada $z$ njegovim estetskim učinkom oz. pomenom, ${ }^{98}$ kot je to $\mathrm{v}$ primeru zadnje teme $\mathrm{v}$ zadnji, nedokončani fugi iz Umetnosti fuge. Vendar se ob prebiranju spisa o Umetnosti fuge zdi, da je Eggebrecht s tem, ko je skušal najti simbolni pomen vseh treh tem zadnje fuge in jih povezati v skrito sporočilo, prestopil meje, ki jih je ugotavljanju glasbenih simbolov sicer razumno postavil sam. ${ }^{99}$

$\mathrm{Za}$ izhodišče razmišljanja o glasbenih simbolih si je treba uzavestiti razloček med estetskim učinkom glasbe, estetskim pomenom, in pomenom, ki ga nosi glasbeni simbol. ${ }^{100}$ Ob poslušanju in dojemanju glasbe navadno ne štejemo tonov in seštevkom

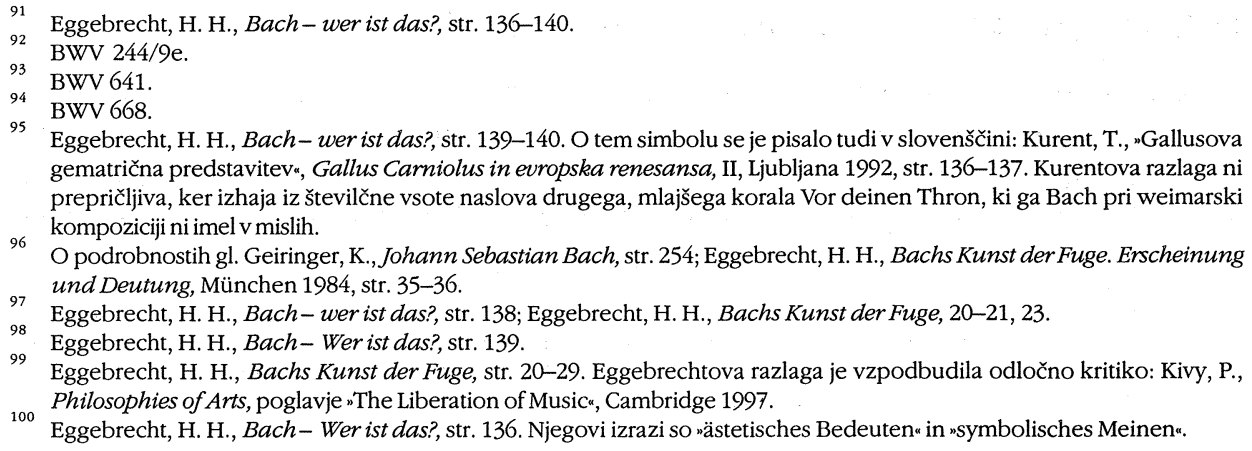


ne pridodajamo pomenov; ob poslušanju obeh imenovanih koralnih preludijev navadno ne bi bili pozorni na število tonov in ob koncu weimarskega koralnega preludija nobenemu, še tako pozornemu poslušalcu ne bi prišlo na misel, da ima parafrazirana melodija natanko 158 tonov, ki pomenijo - prevedeni v eno od možnih kombinacij ustreznih črk - avtorjevo ime. Prav tako si ob poslušanju glasbe ne zamišljamo imen tonov, ki so vrhu vsega v različnih jezikih različni, in jih ne sestavljamo v besede, katerih pomeni bi nam bili ključ do razumevanja poslušane glasbe. Vse to bi odvračalo pozornost od glasbe same. Glasbena simbolika je gledano s tega stališča povsem zunaj glasbe oz. zunaj njenega estetskega učinkovanja (estetskega pomena). Če pa je tako, potem je iskanje glasbenih simbolov v Bachovi glasbi sicer možno in zanimivo početje, vendar zunaj vprašanjo Bachovi glasbi kot taki.

Slednja trditev je sicer preverljivo zanesljiva, a kljub temu se zdi, da ostaja pri Bachovi glasbeni simboliki nekaj nepojasnjeno. Zakaj se ji je posvečal? Vrnimo se na najočitnejši glasbeni simbol v Bachovi glasbi, k temi b-a-c'-h. Neobremenjeni poslušalec, ki niti ne bi vedel za ime avtorja kompozicije, simbola nikakor ne bi mogel prepoznati in če bi že slučajno sestavil imena tonov teme v besedo, ni nujno, da bi jo razumel kot osebno ime avtorja kompozicije. A z Bachom je bilo na tem mestu kompozicije drugače: po dolgem preizkušanju možnih kontrapunktskih rešitev, po dolgem iskanju poti po zapletenih kontrapunktskih labirintih je bil na mestu, kjer se pojavi tema s simbolnim pomenom, tik pred tem, da ustvari z nameravanim zaključkom trojne fuge dovršeno kontrapunktsko sintezo in hkrati dovršen kompozicijski exitus, razrešitev, za katero si je upravičeno lahko mislil, da je korpus do njegovega časa ustvarjene glasbe takšne še ni poznal. Vpeljavo glasbenega simbola b-a-c'-h je tako mogoče videti kot odraz njegove zavesti o samem sebi v posebno pomenljivem glasbenem trenutku njegovega dela. Na podoben način bi lahko razmišljali ob številu $158 \mathrm{v}$ njegovi weimarski kompoziciji. Če predpostavimo, da je to število tonov $\mathrm{v}$ parafraziranem koralu $\mathrm{v}$ resnici glasbeni simbol, si lahko predstavljamo, da si je skladatelj mislil takole: "To sem jaz, Johann Sebastian Bach, ki na svoj lastni način govorim Wenn wir in..." Iz teh razmišljanj lahko povzamemo: Glasbeni simboli niso odraz skladateljevih teženj navzven, ne govorijo poslušalcu in ne morejo biti skladateljeva sporočila poslušalcem, pač pa so, obrnjeni navznoter, priča skladateljevega odnosa do samega sebe. Glasbeni simboli, zakriti očem oz. ušesom poslušalcev, kažejo na odnos skladatelja do samega sebe in taki sodijo v skladateljevo umetniško zasebnost. ${ }^{101}$

\section{Pota do strukturne globine Bachove glasbe}

Kljub temu, da se je veličina Bachovega genija poskušala videti med drugim tudi v zunajglasbenem, na primer $\mathrm{v}$ njegovi religioznosti, se ob prebiranju literature o njem vendarle zdi, da je tisto, zaradi česar je bila Bachova glasba zlasti prepoznavana za veliko, neprekosljivo skladateljsko mojstrstvo, tako ali drugače očitno domala v vsakem njegovem

${ }^{101}$ Eggebrecht je problem Bachovih glasbenih simbolov rešil drugače. Oprl se je na namembnost Bachove glasbe, kot naj bi jo pojmoval Bach sam, po katerega izjavi njegova glasba ni bila namenjena ljudem, pač pa predvsem Bogu. (Gl. Bachovo izjavo, navedeno v drugem odstavku podpoglavja o religioznosti Bachove glasbe.) Ob predpostavki, da se Bach s svojo glasbo in z vsem, kar bi mogla biti in pomeniti, ni oziral na poslušalce, dobijo njegovi glasbeni simboli drugačen pomen. Gl. Bach-wer ist das?, str. 142. 
delu. V literaturi o Bachu se tako pogosto bere o mojstrskih izpeljavah, domišljeni simetriji itd. Bachovo mojstrstvo je bilo znano njegovim sodobnim kritikom, tako tudi Scheibeju; izrecno ga je poudarjal njegov sin Carl Philipp Emanuel Bach, ${ }^{102}$ tudi sam do popolnosti dovršen skladatelj, ne nazadnje po zaslugi svojega očeta. Prav zaradi kompozicijskotehničnega mojstrstva je Bachov opus v 19. stol. postal ena od obveznih osnov kompozicijskega uka, zlasti v obliki izdelovanja fug po mojstrovih vzorcih, saj je za Bachove fuge obveljalo, da predstavljajo bistvo njegovega kompozicijskega mišljenja in dovršene primere popolnega obvladanja oblike. Najbrž je ravno prepoznanje Bachovega kompozicijskega mojstrstva vodilo $k$ analitičnim obravnavam njegovih del, čeprav si je mogoče misliti, da jim je bila hkratna vzpodbuda tudi vprašanje, v čem je skrit oz. od česa je odvisen njihov tako močan in izrazit estetski učinek.

Kompozicije, skladateljska glasbena dela se kot glasbene strukture v najširšem pomenu besede odpirajo vsakršnim analitičnim postopkom; bodisi takim, ki jih je poznala ali omogočala glasbena teorija dobe, v kateri so nastala, bodisi tistim, ki so jih omogočila šele kasnejša odkritja raznovrstnih povezav znotraj koherentnih, zaključenih glasbenih del, razvita pogosto na glasbi svojega časa. Razumljivo je, da so postale Bachove kompozicije, prepoznane kot delo genialnega glasbenika, predmet mnogoštevilnih in raznovrstnih analitičnih obravnav, še pogosteje analitičnih komentarjev; a skladno z razvojem glasbenoanalitičnih iskanj so se analitični vpogledi v Bachovo glasbo menjali in zdi se, kot da bi se stalno poglabljali.

Običajni analitični pristopi k Bachovi glasbi, kakršni so se uveljavili med drugim tudi v glasbenem šolstvu, razlagajo Bachove kompozicije v smislu nauka o glasbenih oblikah, funkcijske harmonije; ko gre za skladateljsko izdelavo dejanskega glasbenega toka, ko gre za dejanski potek glasov pa v smislu nauka o kontrapunktu. Same analize so tako aplikacije nauka o oblikah, harmoniji in nauka o kontrapunktu na izbrane skladbe, aplikacije, ki pokažejo, na kakšen način je v obravnavani skladbi uresničena ideja oblike, ki ji skladba pripada, ideja funkcijske tonalnosti, ter kako je z ozirom na medsebojne odnose glasov kompozicija dejansko izpeljana. Tovrstne analize, katerih odlične primere pozna tudi slovensko glasboslovje, ${ }^{103}$ so zanesljivi vodniki po Bachovem opusu, v katerem je vsaka kompozicija oblikovno na izvirni način samosvoja. Vendar pa ostajajo analize, narejene s stališča ustaljenega nauka o oblikoslovju, funkcionalni harmoniji in kontrapunktu na ravni domnevno objektivnega opisovanja dejanskega poteka izbrane skladbe, opisovanja, ki ne more prodreti in zaobjeti tistega bistva kompozicije, ki ga je mogoče imeti za jamstvo in merilo njene koherentnosti, celostnosti, obenem s tem pa tudi njene svojskosti. Gotovo je bil tudi to eden od razlogov, zakaj so se v zadnjem stoletju pojavili drugačni analitični pristopi, taki, ki so skušali prodreti v skrivnostne globine analiziranih del in med katerimi je izstopajoč zlasti Schenkerjev pristop. Ob Schenkerjevih analitičnih obravnavah se po skorajda stoletni časovni distanci lahko vprašamo, kaj te analize so, kaj razkrivajo in kaj morejo povedati o analizirani glasbi.

102 Tako na primerv uvodu k izdaji štiriglasnih Bachovih koralov leta 1765 (Reich, W., nav. delo, str. 196), v oglasu za razprodajo tiskane izdaje Umetnosti fuge (nav. delo, str. 189-190) ali pa v pismu Ch. Burneyu, objavljenem v njegovem Tagebuch meiner musikalischen Reisen, 3, Hamburg 1773 (nav. delo, str. 164).

103 Škerjanc, L. M., Kontrapunkt in fuga, II, Ljubljana 1956. Podoben analitični vpogled v fuge Dobro temperiranega klavirja I daje Czaczkes, L., Analyse des Wohltemperierten Klaviers, I, Dunaj 1965. 
Med mnogimi Schenkerjevimi analizami je tudi analiza Bachovega Preludija I iz zbirke Dobro temperirani klavir I. ${ }^{104}$ Skladno s Schenkerjevo metodo so tudi v tej analizi $s$ postopnim odmišljanjem površinskega prikazane različno globoke strukturne plasti, dokler ni skladba slednjič zvedena na golo osnovo. Ta je zgolj avtentična kadenca, ki jo schenkerjanska analiza, kot je znano, razpoznava kot temelj vseh tonalnih glasbenih del. $Z$ razkrivanjem kompozicije in odkrivanjem njenih globljih plasti Schenkerjeva analiza implicira, da so te, globlje strukturne ravni v kompoziciji resnično prisotne, prisotne enako realno kot tisto, kar je Bach dejansko zapisal: odkriva jih analiza in s tem, ko jih odkriva, potrjuje tudi njihov obstoj. Schenkerjeva analiza Bachovemu preludiju sicer nič ne dodaja in $v$ tem smislu je vse, kar odkriva v njem, $v$ preludiju tudi prisotno. A tiste avtentične kadence, ki naj bi bila osnova vsej skladbi, njena najgloblja strukturna plast, Bach vendar ni zapisal in tudi poslušalec je ne sliši na tak način kot na primer razširjeno avtentično kadenco prav na začetku skladbe. Način obstoja različno globokih plasti tega Preludija je očitno drugačen kot način obstoja njegove slišne površine.

V zvezi z nakazanim vprašanjem je zanimiva Scrutonova kritika Schenkerjevih analitičnih postopkov, izpeljana med drugim tudi iz Schenkerjeve analize Preludija I iz zbirke Dobro temperirani klavir I. ${ }^{105}$ Scruton vidi in razumeva globinsko kot skrito; če svobodno interpretiramo Scrutonovo misel, moremo reči, da so Schenkerjeve strukturne ravni $v$ analizirani glasbi sicer prisotne, a ne v generativnem smislu; ne tako, da bi celotna kompozicija izhajala, se porajala iz osnovnega stavka, ki bi bil torej realna osnova skladbe in ki je po Schenkerju vedno le avtentična kadenca, pač pa tako, da nakazujejo notranje povezave med posameznimi deli kompozicije. ${ }^{106}$ Schenkerjeva osnovna melodična linija kompozicije (e"-d"-c'; melodična linija zgornjega glasu avtentične kadence, ki je po Schenkerju osnovna strukturna plast kompozicije, iz katere izhaja vse ostalo in ki je izvedena iz prvega in zadnjih dveh taktov skladbe) torej ni osnovna $v$ tem smislu, da bi pomenila generativno zasnovo: ni resnična na ta način, da bi iz nje izhajala celotna skladba; realna pa je osnovna melodična linija na ta način, da je ob poslušanju oz. interpretiranju skladbe mogoče povezati in podoživeti prav te tri tone. To pomeni: na koncu kompozicije lahko poslušalec v svoji glasbeni fantaziji - zavestno ali nezavedno - vzpostavi povezavo med zadnjima dvema tonoma sopranskega glasu, prisotnima v obliki klavirskoidiomatske figuracije, s sopranskim tonom prvega takta.

Podobno je mogoče soditi tudi ob drugih Schenkerjevih zaznavah, kot so: izpostavitev padajoče kromatične linije, ki jo je mogoče slišati med altom in tenorjem v taktih 11-15; namig na povezavo med dvema po kvintnem krogu sosednjima tonoma es in as $\mathrm{v}$ izredno občutljivih taktih 22 in 23 , čeprav nastopata imenovana tona kot sestavna dela funkcijsko zelo oddaljenih akordov: es kot del akorda $\mathrm{z}$ dominantnega področja (dvojna dominanta fis-a-c-es), as pa kot del akorda s subdominantnega pola (as-c-d-f, terckvartakord druge stopnje z znižano kvinto, kar je funkcijsko molovska subdominanta $\mathrm{z}$ dodano seksto, vendar v terckvartakordnem obratu); izpostavitev sopranskih decim v ključnih akordih kompozicije itd.

\footnotetext{
${ }_{104}$ BWV 846/1. Schenker, H., Five Graphic Music Analyses, New York 1969, str. 36-37.

${ }_{105}$ Scruton, R., The Aesthetics of Music, Oxford 1997, str. 417-419.

106 Scruton, R., nav. delo, str. 424-425.
} 


\section{MUZIKOLOŠKI ZBORNIK • MUSICOLOGICAL ANNUAL XXXVI}

Očitno je, da izhaja Schenkerjeva analiza iz zelo globokega in glasbeno skrajno občutljivega razumevanja Bachovega Preludija, razumevanja, ki razkriva mnogovrstne povezave v tem Bachovem do skrajnosti pretehtanem delu. A povezave, ki jih je odkrila Schenkerjeva analiza, niso realne na tak način kot tisto, kar je Bach dejansko zapisal; $v$ Preludiju bi bilo enako legitimno mogoče sprevideti in vzpostaviti povezave, ki jih Schenker ni označil, kot bi bilo mogoče nekatere od tistih, ki jih je zaznal, tudi prezreti. To pomeni, da Schenkerjeva analiza ne more biti odkritje skrite, vendar objektivne realnosti, ki bi bila v skladbi prisotna na enak način kot tisto, kar je Bach dejansko zapisal in kar poslušalec sliši in sproti dojema. Če pa Schenkerjeva analiza ni odkritje objektivne realnosti, je lahko le interpretacija. $Z$ drugimi besedami: če razumemo Schenkerjevo analizo kot analizo, tedaj to ni Schenkerjeva analiza Bachovega Preludija, pač pa analiza Schenkerjevega lastnega doživljanja te Bachove klasične mojstrovine.

Če se v luči zaključka v zvezi s Schenkerjevo analizo povrnemo k vprašanju, v čem obstoji svojskost in izrednost Bachove glasbe, in če z logično ostrino motrimo izjave in izsledke raznovrstnega razpravljanja o njej, je očitno tole: Sodbe o Bachu in njegovi glasbi, dobljene preko raznovrstnih obravnavanjskih postopkov ali osebnih videnj, sicer indicirajo, nakazujejo njeno svojskost in enkratnost, a izrecno je ne morejo dokazati. $\mathrm{Na}$ Bachovem življenju ni v primerjavi z življenjem njegovih sodobnikov nič posebnega in njegova glasba ni osebnoizpovedni izraz njegove morebitne izredne življenjske usode; analogno temu tudi religioznost njegove glasbe $v$ primerjavi $z$ glasbo njegovega časa in okolja ni ne posebna ne enkratna; glasbenozgodovinopisni prikazi J. S. Bacha, zlasti tisti, ki se strožje omejujejo na svoj predmet, nimajo orodij, z izjemo kritiških sodb, s katerimi bi celovito prikazali njeno svojskost; glasbeni simboli poslušalcu ne morejo sporočati ničesar; a tudi tisti pristopi, ki se ukvarjajo z Bachovo glasbo samo, se pravi analitični pristopi, je ne morejo izčrpati. Razpravljanje o Bachovi glasbi, čeprav izhaja iz nje same, ne more biti enakovreden prenos njenega estetskega bistva. V skladu z gledanjem, da je glasbena stvaritev glasba le toliko, kolikor obstoji kot estetski učinek, ostaja tisto, kar Bachova glasba dejansko je, dojemljivo in preverljivo le znotraj samega glasbenoizkustvenega sveta. 


\title{
Johann Sebastian Bach:
}

\section{The Utterable Scholarly Account and the Unutter- able Greatness of Music}

\begin{abstract}
Summary
Bach's music, whose characteristics were well recognized in his own time as can be seen from Scheibe's writings, became regarded as the work of an outstanding composer only a century after his death; yet in the process of his becoming a musical oracle of the past, Bach began to be understood and conceptualized in terms foreign to his own historical surroundings. As a consequence, a gap between the real historical Bach on the one side and his canonized picture on the other came into being. In scholarly literature on Bach there are various suggestions and observations in respect of the exceptional value of his music. A closer, scrutinizing examination of such observations reveals that they may point to the outstanding characteristics of his music, whose aesthetic essence, however, still cannot be conveyed in terms of logical verbal expressions. There is nothing in Bach's life that could be considered particularly outstanding, and his music, having been composed for the most part for special occasions, cannot be understood as the expression of the inner self of an exceptional human being. A historical approach to his music does not have the means to measure its value as compared to his predecessors and contemporaries apart from subjective critical judgement. The alleged religiosity of his music pales when juxtaposed to the standards of ordinary church music making in his own time. Rather, it is only from the standpoint of the modern secularized society that the religious quality of his music becomes evident. The hidden messages of his musical symbols do not impact the aesthetic qualities of his music; attesting rather to the composer's attitude towards himself they do not convey anything to the listener. As for the analytical approach, it was the Schenkerian analysis that promised to reveal the depths of Bach's music; yet according to Scruton's critical judgement, the Schenkerian analysis might be understood as an analysis of the experience of Bach's music rather than an objective analysis of the music itself. Thus the music of Bach cannot be comprehended and appreciated except within the domain of purely musical experience.
\end{abstract}

